\title{
Why do some Consumers Consume Ethically? A Contingency Framework for Understanding Ethical Decision Making
}

\author{
Muhammad Atif ${ }^{1}$, Ahmed Anis Charfi ${ }^{2}$ and Eric Lombardot ${ }^{3}$ \\ ${ }^{1}$ Organization Management and Entrepreneurship, Burgundy School of business, Dijon, France \\ ${ }^{2}$ European Business School-Paris (France), Research center IREBS, Paris, France \\ ${ }^{3}$ Université Paris 1 Panthéon-Sorbonne, Laboratoire PRISM, Paris, France.
}

Correspondence should be addressed to: Muhammad Atif; mak1to1@gmail.com

Received date: 25 May 2013; Accepted date: 28 July 2013; Published date: 20 November 2013

Academic editor: Nasrin Shah-Abushakra

Copyright (C) 2013. Muhammad Atif, Ahmed Anis Charfi and Eric Lombardot. Distributed under Creative Commons CC-BY 3.0

\begin{abstract}
Although consumers' generally have positive attitudes towards ethically conscious behaviors, their actions are not unequivocally consistent with attitudes. Consumer research to understand the adoption of ethically conscious behaviors is therefore important. This paper makes a crosscultural analysis of consumers' ethical decision making process in the context of environment consciousness (Europe, USA and China). A model of individual ethical decision making is presented and tested empirically. We suggest that the information targeted to convince the consumers to engage in ethically conscious behaviors should appeal three subdivisions of their belief structure; the information part, the concern part, and the self-belief part.
\end{abstract}

Keywords: Ethically Conscious Behavior, Ethical consumption, Ethical Decision Making, Identity Theory, Theory of Planned Behavior.

\section{Introduction}

In recent years products carrying sustainability attributes (Vermeir \& Verbeke,
2008) and ethical claims (d'Astous \& Legendre, 2008) have become increasingly appealing to consumers. The number of consumers, who consciously consume ethical

Cite this Article as: Muhammad Atif, Ahmed Anis Charfi and Eric Lombardot (2013), "Why do Some Consumers Consume Ethically? A Contingency Framework for Understanding Ethical Decision Making ", Journal of Marketing Research and Case Studies, Vol. 2013 (2013), Article ID 420183, DOI: $10.5171 / 2013.420183$. 
or sustainable products, is on increase (Crane, 2001) and most of the consumers hold positive attitudes towards such products. However, the relative market shares of products carrying ethical attributes are fairly low (d'Astous \& Legendre, 2008; Aertsens et al., 2009; Willer \& Kilcher, 2009; Eckhardt et al., 2010). Therefore, there is a significant difference between what consumers say about ethical and sustainable consumption and their actual behavior (Vermeir \& Verbeke, 2006). An ample amount of research exists on this attitudebehavior divergence. Researchers have come up with various situational factors that impede or inhibit ethical behaviors and ethical consumption (Hughner et al., 2007; Aertsens et al., 2009; Bray et al., 2010). Table 1 lists down these factors. However, an indepth understanding of consumers' ethical decision-making (Vermeir \& Verbeke, 2006; Michaelidou \& Hassan, 2008), particularly from the psychological perspective (Hughner et al., 2007; d'Astous \& Legendre, 2008) is still lacking.

We consider that a better understanding of ethical consumption demands a deeper analysis of consumers' ethical decisionmaking and their ethically conscious behaviors. We further suggest that consumers' ethically conscious behaviors are linked to consumers' awareness and perception of an ethical issue. A very few studies have explored the link between an ethical issue and consumers' ethical decisionmaking empirically. Moreover, literature on how individual differences influence consumers' issue awareness process in the context of ethical decision-making is scarce (Reynolds, 2006). From the practitioners' point of view, the identification of consumer having concern for specific ethical issues, and as a result interested in ethical products/solutions is quite appealing. Majority of the ethical decision-making models proposed within the broad area of business ethics (Nicholls \& Lee, 2006); approach the issue from an organizational perspective, and often without empirical support (Bray et al., 2010). Comparatively little, attention has been given to the individual ethical decision-making (Nicholls \& Lee, 2006).

A comprehensive examination of ethical consumption requires an in-depth analysis of consumers' ethical decision-making and ethically conscious behaviors. Hence, the aim of this paper is first, to understand why does an individual consumer behave in an ethically conscious way? And particularly study the factors that stimulate the consumers during their decision-making process towards ethical consumption despite the opportunities and incentives of doing otherwise. Second purpose of this article is to offer an issue contingent model of consumers' ethical decision-making that builds on and supplements prior models of ethical decision-making originating from diverse theoretical approaches and backgrounds. Last, the objective is to formulate suggestions for stimulating and promoting ethical consumption among specific consumer segments.

In this study we have taken 'climate change' as a test case for an ethical issue. Further we have demonstrated the link between environmental consciousness to environmentally conscious behaviors through a process of cognitive development and identity formation. This study has been carried out across five countries spread over three continents - France, Germany, Spain, USA and China. The choice of multiple countries with varied cultural backgrounds is inspired by the notion that certain types of values or beliefs may be regarded as more important to individuals in one country than individuals in another country (Kim et al., 2002). A cross - cultural analysis could not only help identify the similarities and the differences between the ethical consumption patterns of the consumers from various countries, but also enhance the generalizability of the model. What has been issue is not if consumers have the potential to consume ethically, but rather the factors that may come into play in their decision-making process and how they could affect their behaviors. Few studies, if any, have addressed issue contingent ethical decision- 
making across among individual consumers, in different countries and cultures. This gap in the literature offers us an opportunity to make a significant contribution.

\section{Review of Theoretical Foundations}

In the following subsections, we briefly discuss the term ethical consumption, followed by a short account of two bodies of socio-psychological research i.e. theory of planned behavior and identity theory, in the context of ethical consumption. Than we present a short overview of mentioned theories. Further, we review some relevant ethical decision-making models, and in light of the discussion an issue contingent model of ethical consumption is proposed with hypothesized structural linkages among variables. Later, we review the objectives of this paper and their relevance to ethical consumption discourse. Subsequently, we describe the methodology used in the analysis and its appropriateness in the given context. In the next section, we present some of the key research results. We conclude with research implications, findings, and limitations.

\section{Ethical Consumption}

Two terms are quite frequently used in the context of ethically conscious behavior i.e. sustainable consumption and ethical consumption. Sustainable consumption is defined as the use of services or products which respond to basic needs and bring a better quality of life while minimizing the use of natural resources and toxic materials as well as emissions of waste and pollutants over the life cycle of the service or product so as not to jeopardize the needs of future generations (Oslo Roundtable on Sustainable Production and Consumption, 1994달. At consumer level, it suggests a decision-making process whereby an individual takes his environmental and social responsibility into account in addition to personal needs and

\footnotetext{
1 Oslo Roundtable on Sustainable Production and Consumption. (1994). Norwegian Ministry of the Environment retrieved on July 14, 2011, from http://www.iisd.ca/consume/oslo004.html
}

wants (Vermeir \& Verbeke, 2006). Whereas Ethical consumption implies that consumers feel responsible towards the society and take social concerns into consideration in their purchase behavior (Browne, et al., 2000; Carrigan, et al., 2004). Ethical consumption does no longer only refer to classical 'fair trade' aspects, such as higher and more stable prices for farmers in developing countries. Instead, it covers issues like the reduction of green house gases, protection of the tropical rainforest, animal welfare, prevention of child labor, labor working conditions, local buying, or employment of handicapped people (Vermeir \& Verbeke, 2006; Zander \& Hamm, 2010). Moreover, ethical consumption means not only the purchase of products or services that have comparatively less impact on environment, but also the way the products are consumed is sustainable (Harrison \& Shaw, 2005). Despite the fact that sustainable consumption is more inclined towards environmental and ecological dimensions, while ethical consumption focusing more on social issues, clearly these terms overlap, and this why often interchangeably used. For clarity and comprehension, we will refer to ethical consumption and sustainable consumption, under the rubric of ethical consumption in the subsequent discussion.

As discussed earlier, consumers generally have very positive attitudes towards ethical consumption, but their actual behavior is much less apparent. Even though several papers report this intention-behavior divergence, thorough understanding of consumers' ethical decision-making is still lacking (Vermeir \& Verbeke, 2006; Michaelidou \& Hassan, 2008; Bray et al., 2010). We consider that it is imperative to link ethical issues with consumers' ethically conscious behaviors. The identification of consumer having specific concern for ethical issues, and thus, interested in ethical solutions or behaviors is quite appealing from a managerial and marketing perspective.

In this paper we approach ethical consumption from a different viewpoint. 
Instead of discussing why consumers do not engage in ethically conscious behaviors, we ask: why do some consumers engage in such behaviors? Considering the barriers for ethical consumptions, and the incentives and the opportunities for following egocentric motives, why does an individual consumer act in ethically conscious way? We do so by drawing on insights from two bodies of socio-psychological research: The theory of planned behavior and the identity theory. Generally speaking, what is important about these theories is that they focus on volitional human behavior in a certain social context. In the area of ethical decision-making, theory of planned behavior (Chan, 1998; Shaw \& Shiu, 2002a; Shaw \& Shiu, 2002b; Shaw \& Shiu, 2003; Saba \& Messina, 2003; Chen, 2007; Gracia \& de Magistris, 2007) and identity theory (Conner \& Armitage, 1998; Reynolds, 2006; Thorbjørnsen et al., 2007) have been frequently employed.

\section{Theory of Planned Behavior}

Theory of Planned behavior (TPA) is an extension of theory of reasoned action (TRA), both explaining the decision-making process of an individual based on careful consideration of available information (Conner \& Armitage, 1998). The difference lies in the nature of behavior under observation. TRA is somewhat limited in the sense that it restricts itself to volitional behaviors. Whereas, TPB is equally capable of predicting volitional as well as non volitional behaviors by adding 'control parameters' to TRA framework (Ajzen, 1991; Conner \& Armitage, 1998; Ajzen, 2001). According to the theory, human behavior is guided by three kinds of considerations: beliefs about the likely consequences of the behavior (behavioral beliefs), beliefs about the normative expectations of others, and beliefs about the presence of factors that may facilitate or impede performance of the behavior (control beliefs). Control beliefs provide the basis for perception of behavioral control of an individual in a given situation (Ajzen, 2001).

\section{Identity Theory}

Identity theory is a socio-psychological theory, which links self attitudes, or identities, to the role relationships and rolerelated behavior of individuals thus offering an explanation of the individual choice making. Identity theorists argue that the self consists of a collection of identities, each of which is based on occupying a particular role (Stryker, 2000; Conner \& Armitage, 1998; Armitage \& Conner, 2001). Contributions on self-identity-related theories have expanded TPB and TRA by including self-identity as a predictor of intentions, independent of subjective norms (normative beliefs) (Thorbjørnsen et al., 2007). A host of studies establish a link between ethical identity and (un)ethical actions (Thorbjørnsen et al., 2007; Shao, Aquino \& Freeman, 2008; Smith et al., 2008). In particular, research shows that ethical identity: (1) positively affects every day pro-social behaviors like charitable giving, (2) negatively affects antisocial behaviors, (3) exerts a stronger impact on behaviors when its accessibility is temporarily increased, and (4) affects mediators of behavior such as moral evaluations, emotions, and judgments. (Shao, Aquino \& Freeman, 2008). Identity theory and TPB behavior resemble in the sense that both argue a rational decision-making approach. The difference however lies in the scope; TPB dealing in psychological and normative aspects whereas identity theory encompassing the broader social context (Conner \& Armitage, 1998).

In the following section, and sub-sections we discuss basics of an issue contingent ethical decision-making model, in light of afore mentioned theoretical approaches. Then we analyze the various elements of the model separately, and propose a model of ethical consumption for empirical testing.

\section{Ethical Decision-Making Models}

Cooper-Martin and Holbrook (1993) define ethically conscious behavior of consumers as 'decision-making, purchases and other consumption experiences that are affected by the consumer's ethical concerns' (Bray et al., 
2010). A number of ethical decision-making models have been proposed within the broad area of business ethics (Nicholls \& Lee, 2006). However, mostly are intended to model general decision-making rather than being specifically concerned with consumption decisions (Nicholls \& Lee, 2006). Moreover, these ethical decisionmaking models generally approach the issue from an organizational perspective, often without empirical support (Bray et al., 2010). Comparatively little attention has been given to the role that ethics plays in individual purchasing behavior.

Amongst the well known models of ethical decision-making is that of (Rest, 1986). He proposes a version of the planned behavior model, in which individuals pass through four consecutive stages towards an ethical decision:

- Recognition of the ethical issue;

- Making ethical judgment;

- Resolution to place ethical concerns ahead of others; and

- Action on the ethical issue

He argued that each component in the process is conceptually distinct and that success in one stage does not imply success in any other stage (Jones, 1991). However, Reynolds (2006) asserts that the stages of ethical decision-making may not be discrete elements of a formulaic thought process, but may actually be interrelated in a very complex manner.

Rest's model is though quite parsimonious, yet contains all the key elements of an issue contingent ethical decision-making model (Reynolds, 2006). Jones (1991) added a new construct in the Rest's model i.e. Moral Intensity. He maintains that the moral intensity of an issue impacts upon all stages of Rest's model, such that two separate moral issues, simultaneously acknowledged by the consumer, may exert differing levels of influence over the decision process. Jones (1991) described moral intensity as the extent to which an issue, event, or act has characteristics that make it subject to moral consideration, moral judgment, and moral action. Lee et al., (2000) considers that Jones' approach provides 'the most comprehensive synthesis model of ethical decision-making'.

\section{Issue Recognition}

The initiating point of ethical decisionmaking models is the identification of an ethical issue (Hunt \& Vitell, 1986; Trevino, 1986). Rest (1986) argued that moral awareness is something of an interpretive process wherein the individual recognizes that an ethical problem exists in a situation or that a moral standard or principle is relevant to some set of circumstances. Much of this research though has focused on identifying the characteristics of the ethical issue, and, subsequently, very little work has explored how individual differences influence ethical awareness (Reynolds, 2006). Given that ethical awareness is an individual-level phenomenon and the characteristics of an ethical issue vary in saliency and vividness, it is possible that one person recognizes an issue as an ethical issue, whereas another does not, due to individual differences. Individuals make judgments of the moral intensity of the issue, and these personal judgments are often sufficient for individuals to form critical distinctions (Jones, 1991). Thus, by increasing the likelihood that an individual will pay attention to those characteristics may augment the probabilities of an issue being considered as a moral or ethical issue (Reynolds, 2006).

In the case of environmental conscious individuals, an ethical consumer is the one who knows that the production, distribution, use, and disposal of products lead to external costs, and who evaluates such external costs negatively, trying to minimize them by her/his own behavior (Grunert \& Juhl, 1995). Hence, consumers with a stronger concern for the environment are more likely to purchase products - as a result of their environmental claims - and engage in environmentally conscious behavior like recycling, than those who are less concerned about the environmental issues (Yeonshin \& Choi, 2005). Therefore, for the ethical decision-making to begin, first a person must 
be able to identify the issue. Second, he should feel that he is concerned by that particular issue (Shaw et al., 2000; Reynolds, 2006). Consequently, recognition of a moral issue involves two elements i.e. perceived certainty of occurrence and perceived intensity of concern. Once a person recognizes that a moral issue exists, and that he is concerned by it, he engages in a process of ethical development whereby he evaluates the issue, and makes up his judgments. Therefore, we propose:

H1: Recognition of climate change by a consumer, triggers the process of ethical identity formation.

This directs us to the next section, i.e. ethical identity formation.

\section{Ethical Identity Formation}

Recognition of the issue leads to ethical identity formation process whereby an individual forms his unique issue contingent ethical identity (Jones, 1991). In identity theory 'ethical identity' is defined as a selfconception organized around a set of moral traits (Aquino \& Reed II, 2002). This identity than forms ethical predispositions that shape the criteria used to make ethical decisions (Beauchamp \& Bowie, 2004). Ethical identity research emphasizes on moral self as the driving force behind ethical identity and the desire for self-consistency as providing the motivational impetus for ethical action. Wealth of studies demonstrates a clear link between ethical identity and (un)ethical actions. (Shaw et al., 2000; Shao, Aquino \& Freeman, 2008).

Individual differences, however, play a role in the process of self identification of ethical issues and consequently formation of ethical identities (Shao et al., 2008). The concept of locus of control (Rotter, 1966) posits that some people, called internals, credit themselves with substantial control over events, whereas others, called externals, see events as largely under the control of luck, chance, or other individuals. Locus of control may be related to perceived volition or more specifically to perceived self-belief of an individual and, hence, to ethical identity formation process. The perceived self-belief of an individual, also referred to as perceived consumer effectiveness (PCE) in theory of planned behavior, characterizes the action dimension of an individual's self identity. It signifies the extent to which a consumer believes that his personal efforts can contribute to the solution of a problem (Vermeir \& Verbeke, 2006). High self-belief is necessary to evoke consumers to translate their ethical predispositions into ethically conscious behaviors (Ellen et al., 1991; Lee \& Holden, 1999). The findings of d'Astous \& Legendre (2008) confirm the relevance of the self-belief concept in the context of ethical consumption research.

As follows, consumers who perceive that their individual actions can make a real difference in terms of solving ethical problems are more likely to form strong ethical identities for that particular issue, and consequently will engage in ethically conscious behavior. Therefore, it is valuable to present the arguments in the following hypothesis,

H2a: Consumer's ethical identity influences consumer's ethically conscious behavior.

\section{Ethical Intention}

Once a person has made an ethical predisposition, - a development that is dependent on his or her ethical identity process (Rest, 1986), - he or she must decide what to do. A decision about what is ethically correct, an ethical judgment, is not the same as a decision to act on that judgment, that is to establish ethical intent (Jones, 1991). The term intent is functionally equivalent to the word intentions, which is found in some of the social psychology literature (e.g. Fishbein \& Ajzen, 1975). At this stage, individuals balance moral factors against other factors, notably the self-interest. Hunt \& Vitell (1986) as well as Rest (1986) explicitly included this step in their models whereas Trevino (1986) and Ferrell \& Gresham (1985) assume a direct transition from the ethical predisposition phase to ethical behavior 
(Jones, 1991). Generally speaking, the stronger the intentions to carry out a behavior, more is the likelihood of occurrence of that particular behavior and vice versa (Conner \& Armitage, 1998). Hence, it is valuable to present the arguments in the following hypotheses:

H2b: Consumer's ethical identity helps form ethical intentions.

H2c: Ethical intentions lead to consumer's ethically conscious behavior.

\section{Socio - Demographic Profile of Consumers}

The identification of consumer segments that are more sympathetic toward ethical issues, therefore more inclined to choose ethical products is obviously quite interesting for companies. However, despite a considerable body of research exists in this area, it has so far produced conflicting and confusing findings (Harrison et al., 2005), especially in terms of demographic factors. On the one hand there are studies that claim ethical consciousness to increase with consumers' age, to be greater in female consumers, to increase with affluence and to be greater at lower educational levels. On the other hand, a similar number of authors find no such correlations, and it is suggested that demographic factors are poor predictors of ethical views, for a variety of background reasons (Bray et al., 2010). We assume that the socio-demographic factors may moderate different elements of ethical decision-making model by either modifying the form and/or strength of relationships. There we posit,

H3: Socio-demographic profile of a consumer impacts his ethical identity formation process.

H4: Socio-demographic profile of a consumer impacts his ethically conscious behavior.

This takes us to the last element of our model, i.e. information profile of an ethical consumer.

\section{Information Profile of Consumers}

Consumers' access to clear and credible information on the products/services is an important factor in effective purchasing and consumption decisions. The present day society presents a range of sources electronic media, print media, internet and social media, retail outlets, word of mouth to inform consumers about social issues (Hughner et al., 2007). The less information available and/or the more complex and contradictory the information is, the more uncertain consumers may be about what products to choose. Researchers have highlighted that benefits of ethical solutions are often poorly communicated to consumers, so that they are unable to make informed decisions in accordance with their budget and/or conscience (Vermeir \& Verbeke, 2006). We assume that information should play a key role in our model, particularly in issue recognition and ethical identity formation (Reynolds, 2006; Shao, Aquino \& Freeman, 2008). The well informed individuals are more likely to be aware of issues like environment and sustainability. It follows that consumers who are aware of such issues and who consider these important, may also focus on them on bigger extant during their decision-making process.

Hence, we assume:

H5: Information profile of consumer influences his issue recognition possibilities.

H6: Information profile of consumer influences his ethical identity formation process.

H7: Information profile of consumer influences his ethically conscious behavior.

Figure 1 sums up the proposed issue contingent ethical decision-making model in pictorial form. 


\section{Issue contingent ethical decision-making}

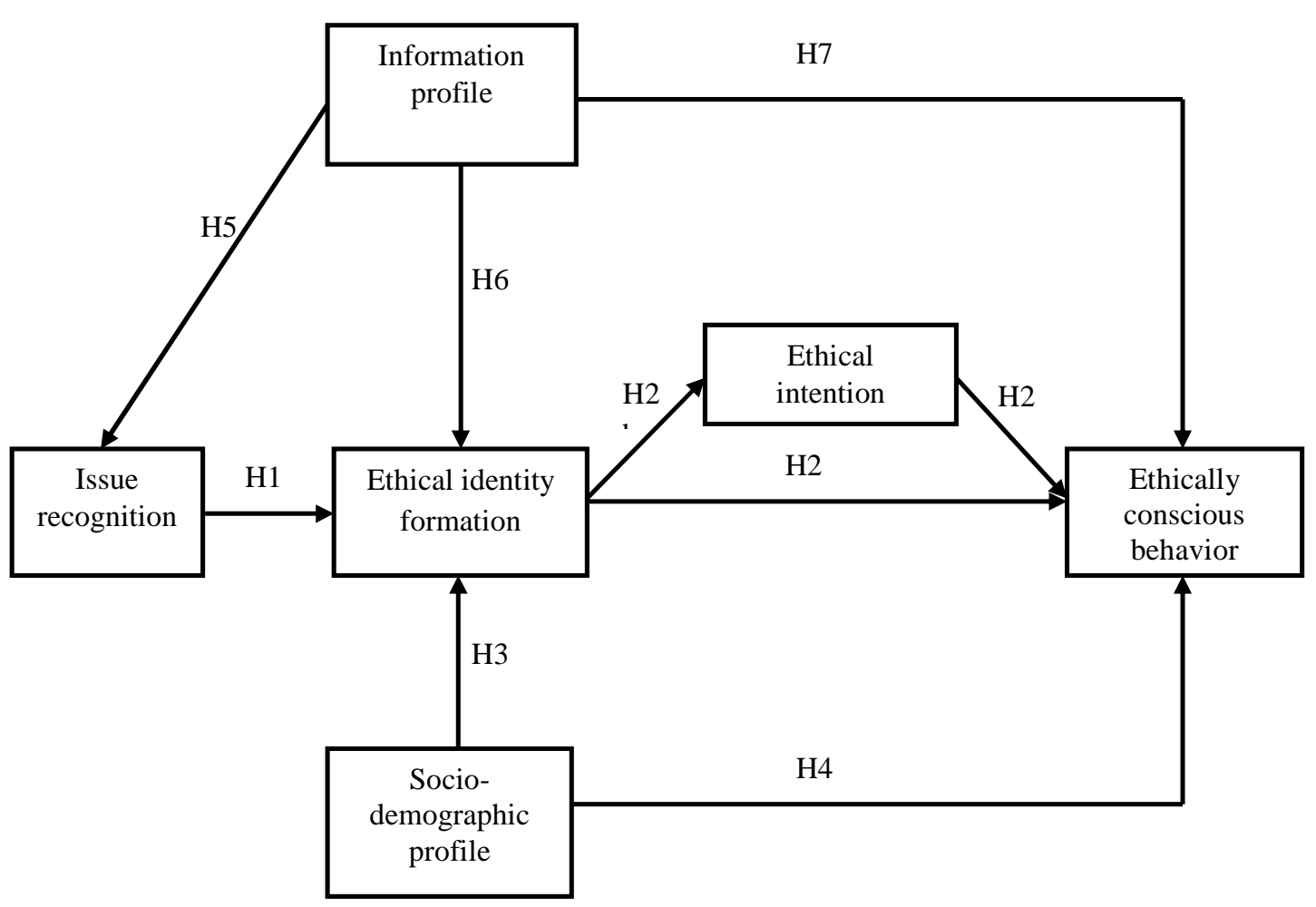

Figure 1: Proposed Conceptual Model and Hypothesis

\section{The Quantitative Study}

For this cross-cultural study we selected three biggest and most influential economies of the world namely, the US, the Euro-zone and China. With regards to Euro-zone, we picked one country each from the Northern Europe and Southern Europe i.e. Germany and Spain. Last selection from Euro-zone is France that lies on the crossroads of Northern and Southern Europe.

\section{Research Method}

To test the assumptions outlined above, we conducted a quantitative study during 2011. Climate change was chosen as a test case for an ethical issue. Further we proposed a model of ethical decision-making linking the environmental consciousness to environmentally conscious behaviors through a process of cognitive development and identity formation. A structured questionnaire was developed in light of the model variables and research questions. Respondents provided the required information on the questionnaire classified into three sections. The final sample consists of 6878 consumers from the five countries, whose age varies between 18 and 64 years.

Table 1 below summarizes the sample details. 
Table 1: Sample Profile

\begin{tabular}{|c|c|c|c|c|c|}
\hline Gender & Age categories & Europe & USA & China & $\begin{array}{c}\text { Total } \\
\text { repartition }\end{array}$ \\
\hline \multirow{8}{*}{ Male } & $16-19$ & 52 & 143 & 104 & 299 \\
\hline & $20-24$ & 111 & 98 & 91 & 300 \\
\hline & $25-29$ & 105 & 113 & 95 & 313 \\
\hline & $30-34$ & 130 & 158 & 130 & 418 \\
\hline & $35-44$ & 281 & 302 & 303 & 886 \\
\hline & $45-54$ & 262 & 243 & 230 & 735 \\
\hline & $55-64$ & 212 & 150 & 0 & 362 \\
\hline & Total & 1153 & 1207 & 953 & 3313 \\
\hline \multirow{8}{*}{ Female } & $16-19$ & 73 & 126 & 101 & 300 \\
\hline & $20-24$ & 138 & 121 & 103 & 362 \\
\hline & $25-29$ & 138 & 140 & 100 & 378 \\
\hline & $30-34$ & 151 & 148 & 131 & 430 \\
\hline & $35-44$ & 293 & 334 & 275 & 902 \\
\hline & $45-54$ & 269 & 270 & 231 & 770 \\
\hline & $55-64$ & 242 & 181 & 0 & 423 \\
\hline & Total & 1304 & 1320 & 941 & 3565 \\
\hline \multicolumn{2}{|c|}{ Total groups } & 2457 & 2527 & 1894 & 6878 \\
\hline
\end{tabular}

Measures Used

A structured questionnaire based on the relevant research objectives was prepared. The survey questionnaire, composed of three sections, included scales aimed at measuring various constructs discussed in the literature review. The variables were all measured on Likert scale, anchored by to "strongly disagree" (1) to "strongly agree" (7), and chosen for their methodological validity and their psychometric qualities. In the first section, i.e. socio-demographic profile, the participants provided information about their gender, age, work status and education. The second section contained three items to measure the information profile of the respondents. The last two sections contained questions related to the research model.

The third section contains items to measure "issue recognition", "ethical identity formation" and "ethical intention". Two items were used to measure "issue recognition". The first item i.e. "I am really concerned about the effects of climate change" was adapted from the ethical concern scale of
(Yeonshin \& Choi, 2005). In line with research work of (Reynolds (2006) another item, i.e. "I think that Climate change (e.g. global warming) is definitely happening", was added to measure the perceived certainty of occurrence of climate change. The construct "ethical identity formation", following two contradictory measures of selfidentity comes from the works of (Shaw \& Shiu, 2003). First, "It's really important that I can treat myself when I want". Second, "It's really important that I do the things which make me a better person rather than just enjoying myself". The third item was designed to tap the action dimension of the consumer's self-identity (see d'Astous \& Legendre, 2008) that is "I am concerned about what I personally can do to help protect the environment". The "ethical intention" part of consumer's cognitive development was measured with an item adopted from (Shaw et al., 2000). The last part contained six items to measure the "ethically conscious behaviors" of the consumers adapted from the scale developed by (Roberts, 1996b). The items measure the extent to which individual consumers believe 
to have a more positive (or less negative) impact on the environment through their consumption behaviors. The questions in the survey were adjusted to enumerate consumers' past behavior (e.g. "I have avoided products with lots of packaging").

\section{Reliability and Validity of Measures}

An exploratory factor analysis was conducted to assess the acceptability constructs. These tests have shown a satisfactory reliability and validity for the various measures used. The Cronbach's alpha of all constructs is acceptable $(>.6)$ and the Jöreskog $\rho$ is greater than .7 (see Table 2). Regarding the convergent validity, it involves measuring a construct with independent measurement techniques and demonstrating a high correlation among the measures (Lin, Gregor \& Ewing 2008). We assessed the internal consistency of the reflective constructs by examining the composite scale reliability index developed by Fornell \& Larcker (1981).

Table 2: Inter-Correlation Matrix

\begin{tabular}{|l|c|c|c|c|c|c|}
\hline & EIF & ECB & IR & EI & $\alpha$ & $\rho$ \\
\hline $\begin{array}{l}\text { Ethical identity } \\
\text { formation(EIF) }\end{array}$ & .721 & & & & .611 & .738 \\
\hline $\begin{array}{l}\text { Ethically conscious } \\
\text { behavior (ECB) }\end{array}$ & $-.352^{* *}$ & .330 & & & .620 & .792 \\
\hline $\begin{array}{l}\text { Issue recognition } \\
\text { IR) }\end{array}$ & $.562^{* *}$ & $-.295^{* *}$ & .716 & & .818 & .834 \\
\hline $\begin{array}{l}\text { Ethical intention } \\
\text { (EI) }\end{array}$ & $.382^{* *}$ & $-.192^{* *}$ & $.397^{* *}$ & 1 & - & - \\
\hline
\end{tabular}

**. Correlation is significant at the 0.01 level (2-tailed).

All of the reliability measures were decently above the recommended levels of .70, indicating satisfactory internal consistency. The discriminate validity was also tested. One criterion for adequate discriminant validity is that the construct represented should share more variance with its measures than it shares with other constructs in the model. In table 2 , the diagonal elements represent the square root of average variance extracted (AVE), providing a measure of the variance shared between each construct and its measures. These elements should be higher than the correlations between the constructs, i.e. the off-diagonal elements in the corresponding rows and the columns in table 2 .

The Empirical Adjustment of the Conceptual Model

A confirmatory factor analysis was conducted to assess the adequacy of the measurement model. The assumed relationships are tested by structural equation models by using the AMOS 7.0 software (Arbuckle, 2006). The analysis result shows a $\chi^{2}=2035.6, \mathrm{p}<.01$, otherwise, the fit indexes indicate that the measurement model produces adequate fit to the data, as evidenced by the goodness-of-fit index (GFI) of .97, adjusted GFI of .95, Bentler-Bonett Index or normed fit index (NFI) of .92, Tucker-Lewis index (TLI) of .91, comparative fit index (CFI) .92 and root mean square error of approximation (RMSEA) of .045 [.043 - .046]. These indicators demonstrate the correct fit of the model; it is therefore within acceptable range (Hair et al., 2006).

\section{Data Analysis and Discussion}

We employed structural equation modeling to model the relationships among the constructs and to test the hypotheses. Thus, we equalized the number $(\mathrm{N})$ of respondents 
in the three regions studied. Then we randomly removed individuals using the software SPSS 18. Table 2 contains the standardized coefficients and t-values for each hypothesized path, the fit indexes, and the squared multiple correlations for each endogenous variable. Model estimates were consistent with each of the paths hypothesized in the proposed model (see Table 3).

The confirmatory factor analysis and the structural equation model fit indicate a proper fit to the data. All hypothesized paths were significant and in the anticipated direction, with the exception of $\mathrm{H} 7$ (Information profile $\rightarrow$ Ethically conscious behavior).The overall structural model has cross-cultural comparability in Europe, USA and China. Yet, the strength of the links between different variables varies among the countries and regions. First, the measure of issue recognitions is found to impact unequivocally the Ethical identity formation process of consumers, thus, supporting $\mathrm{H} 1$ (Issue recognition $\rightarrow$ Ethical identity formation). In general, environmental issues like climate change are not easily tangible. This is why previous studies have suggested a need to enhance the ability of issue recognition in capturing the essence of issue recognition or concern by adding a specific level of certainty. Some studies have also been proved successful in doing this (see for example Reynolds, 2006) with a measure reflecting issue certainty in addition to the awareness factor. We added an item in our questionnaire to gauge the issue certainty perception of consumers. Our results suggest that in the context of issue contingent ethical decision-making it is useful to consider this factor. As a whole, issue recognition is found to have a considerable role in ethical identity formation process. This result holds for all the regions selected in the study.

Table 3: Results of Structural Equation Models: Europe, USA and China

\begin{tabular}{|c|c|c|c|c|c|c|}
\hline & \multicolumn{2}{|c|}{$\begin{array}{c}\text { Europe } \\
(\mathrm{N}=1894)\end{array}$} & \multicolumn{2}{|c|}{$\begin{array}{c}\text { USA } \\
(\mathrm{N}=1894)\end{array}$} & \multicolumn{2}{|c|}{$\begin{array}{c}\text { China } \\
(\mathrm{N}=1894)\end{array}$} \\
\hline Proposed Model Paths & $\mathrm{B}$ & $\mathrm{R}^{2}$ & $\bar{\beta}$ & $\mathrm{R}^{2}$ & $\bar{\beta}$ & $\mathrm{R}^{2}$ \\
\hline $\begin{array}{l}\text { Information profile } \rightarrow \\
\text { Issue recognition }\end{array}$ & $\begin{array}{l}.109^{*} \\
(2.11)\end{array}$ & .02 & $\begin{array}{l}2.46^{*} \\
(2.12)\end{array}$ & .061 & $\begin{array}{l}.527^{* * *} \\
(6.44)\end{array}$ & .278 \\
\hline $\begin{array}{l}\text { Issue recognition } \rightarrow \\
\text { Ethical identity } \\
\text { formation }\end{array}$ & $\begin{array}{l}.782^{* * *} \\
(16,62)\end{array}$ & \multirow{3}{*}{.78} & $\begin{array}{l}.772 * * * \\
(16.78)\end{array}$ & \multirow{3}{*}{.625} & $\begin{array}{c}.681^{* * *} \\
(9.68)\end{array}$ & \multirow{3}{*}{.596} \\
\hline $\begin{array}{l}\text { Socio-demographic } \\
\text { profile } \rightarrow \text { Ethical } \\
\text { identity formation }\end{array}$ & $\begin{array}{c}-.287^{*} \\
(-2.21)\end{array}$ & & $\begin{array}{c}-.124^{* * *} \\
(-4.19)\end{array}$ & & n.s & \\
\hline $\begin{array}{l}\text { Information profile } \\
\rightarrow \text { Ethical identity } \\
\text { formation }\end{array}$ & n.s & & n.s & & $\begin{array}{l}.152^{*} \\
(2.10)\end{array}$ & \\
\hline $\begin{array}{l}\text { Ethical identity } \\
\text { formation } \rightarrow \text { Ethical } \\
\text { intention }\end{array}$ & $\begin{array}{l}.461^{* * *} \\
(14.80)\end{array}$ & .21 & $\begin{array}{l}.574^{* * *} \\
(20.85)\end{array}$ & .330 & $\begin{array}{l}.396^{* * *} \\
(11.34)\end{array}$ & .157 \\
\hline
\end{tabular}




\begin{tabular}{|c|c|c|c|c|c|c|}
\hline & \multicolumn{2}{|c|}{$\begin{array}{c}\text { Europe } \\
(\mathrm{N}=1894)\end{array}$} & \multicolumn{2}{|c|}{$\begin{array}{c}\text { USA } \\
(\mathrm{N}=1894)\end{array}$} & \multicolumn{2}{|c|}{$\begin{array}{c}\text { China } \\
(\mathrm{N}=1894)\end{array}$} \\
\hline $\begin{array}{l}\text { Ethical identity } \\
\text { formation } \rightarrow \text { Ethical } \\
\text { behavior }\end{array}$ & $\begin{array}{c}-.489 * * * \\
(-7.92)\end{array}$ & \multirow{4}{*}{.50} & $\begin{array}{c}-.454^{* * *} \\
(-6.72)\end{array}$ & \multirow{4}{*}{1.722} & n.s & \multirow{4}{*}{.420} \\
\hline $\begin{array}{l}\text { Ethical intention } \rightarrow \\
\text { Ethically conscious } \\
\text { behavior }\end{array}$ & $\begin{array}{l}.151^{* * *} \\
(4.18)\end{array}$ & & $\begin{array}{c}.168^{* * *} \\
(4.25)\end{array}$ & & n.s & \\
\hline $\begin{array}{l}\text { Socio-demographic } \\
\text { profile } \rightarrow \text { Ethically } \\
\text { conscious behavior }\end{array}$ & $\begin{array}{l}.451^{*} \\
(2,01)\end{array}$ & & n.s & & n.s & \\
\hline $\begin{array}{l}\text { Information profile } \\
\rightarrow \text { Ethically conscious } \\
\text { behavior }\end{array}$ & n.s & & n.s & & $\begin{array}{c}-.563^{* * *} \\
(-4.49)\end{array}$ & \\
\hline $\begin{array}{l}* * * \mathrm{p}<.001 ;{ }^{* *} \mathrm{p}<.01 ;{ }^{*} \\
=.88 ; \mathrm{CFI}=.91 \text { and RM } \\
N F I=.91 ; \mathrm{TLI}=.90 ; \mathrm{CFI} \\
.97 ; \mathrm{AGFI}=.96 ; \mathrm{NFI}=.8\end{array}$ & $\begin{array}{l}. \text { Europe } \\
.044[.04 \\
\text { and RMS } \\
=.88 ; \mathrm{Cl}\end{array}$ & $\begin{array}{l}=513 \\
048] . \\
=.047 \\
90 \mathrm{an}\end{array}$ & $\begin{array}{l}110), p<. \\
\chi^{2}=565( \\
-.051] . C \\
\text { SEA }=.04\end{array}$ & $\begin{array}{l}\text { FI }=.97 \\
10), p<. \\
: \chi^{2}=43 \\
36-.044\end{array}$ & $\begin{array}{l}I=.96 ; N F \\
F I=.96 ; A \\
=110), p\end{array}$ & $\begin{array}{l}9 ; \text { TLI } \\
.95 ; \\
\text { GFI = }\end{array}$ \\
\hline
\end{tabular}

Second, ethical identity influences the ethically conscious behavior indirectly via ethical intentions. A clear directional relationship between ethical identity and ethical intention is observed across the board, hence, providing strong support for $\mathrm{H} 2 \mathrm{~b}$ (Ethical identity formation $\rightarrow$ Ethical intention). Ethical intention in turn is found to influence consumer behaviors. This however, does not hold in Chinese data therefore indicating a partial approval of $\mathrm{H} 2 \mathrm{c}$ (Ethical intention $\rightarrow$ Ethically conscious behavior). The mediating role of ethical intention is significant in the model even though it does not complete the loop in case of Chinese data. Additionally identity formation - with the exception of Chinese data - links ethically conscious behaviors of the consumers directly as well thus providing a partial support to hypothesis H2a (Ethical identity formation $\rightarrow$ Ethically conscious behavior).

The most noteworthy cross-cultural variances were the differing relations between ethical identity formation, ethical intention and ethically conscious behavior. In the Chinese data both ethical intentions as well as ethical identity formation were insignificant predictors of ethically conscious behavior. Whereas in Europe and USA; this was the other way around with intentions and ethical development, translating strongly into ethically conscious behaviors. In general, in Chinese consumers, the ethical identity formation, whether in form of ethical intentions or ethical predispositions did not translate in ethical behavior.

Another visible difference between the regions was the influence of sociodemographic and information profile of consumers on their ethically conscious behavior. Conforming to previous researches (see Bray et al., 2010) demographics had mixed impact on the consumers' ethical development and behavior. Sociodemographic profile was significantly linked to ethical identity formation in case of Europe and USA, thus, suggesting an indirect impact of demographics on the ethically conscious behavior and supporting proposed hypothesis H3 (Socio-demographic profile $\rightarrow$ Ethical identity formation). The model accounted for considerable amounts of variation among countries in sociodemographic profile and ethically conscious behavior relationship. Variations in ethically conscious behavior were explained to some extent by socio-demographics in case of Europe. However US and Chinese data did not reveal a significant relationship between 
the two variables thus suggesting only a weak partial support for $\mathrm{H} 4$ (Sociodemographic profile $\rightarrow$ Ethically conscious behavior). Globally speaking, in case of Chinese data socio-demographic profile did not add any considerable prognostic ability to the model.

The information profile of consumers has a valid role on the model as a whole. However, it varies in intensity and impact from region to region. With regards to issue recognition, clearly it is linked to the awareness of consumers, and substantiates the hypotheses H5 (Information profile $\rightarrow$ Issue recognition). This is also in accordance with the previous research (see Reynolds, 2006; Shao, Aquino \& Freeman, 2008; Vermeir \& Verbeke, 2006).
However, the impact of information profile does not have significant direct impact on ethical identity formation in case of European or American consumers. Only in case of Chinese data, it is found to impact the ethical identity formation directly, thus providing a weak partial support to H6 (Information profile $\rightarrow$ Ethical identity formation). Whereas information profile have unclear direct impact on the behavior. In case of European and American consumer, it has no significant impact. But in case of Chinese consumers, it is inversely related to behavior. Therefore, there is little evidence to support H7 (Information profile $\rightarrow$ Ethically conscious behavior), particularly for US and Europe. Table 4 summarizes the above debate.

Table 4: List of Hypothesis Tested for Europe, USA and China

\begin{tabular}{|c|c|c|c|}
\hline Hypotheses & Europe & USA & China \\
\hline $\begin{array}{c}\text { H1: Issue recognition influences ethical identity } \\
\text { formation }\end{array}$ & $\mathrm{Y}$ & $\mathrm{Y}$ & $\mathrm{Y}$ \\
\hline $\begin{array}{c}\text { H2a: Ethical identity formation influences ethical } \\
\text { intention }\end{array}$ & $\mathrm{Y}$ & $\mathrm{Y}$ & $\mathrm{N}$ \\
\hline $\begin{array}{c}\text { H2b: ethical identity formation influences ethically } \\
\text { conscious behavior }\end{array}$ & $\mathrm{Y}$ & $\mathrm{Y}$ & $\mathrm{Y}$ \\
\hline $\begin{array}{c}\text { H2c: Ethical intention influences ethically conscious } \\
\text { behavior }\end{array}$ & $\mathrm{Y}$ & $\mathrm{Y}$ & $\mathrm{N}$ \\
\hline $\begin{array}{c}\text { H3: Socio-demographic profile influences ethical } \\
\text { identity formation }\end{array}$ & $\mathrm{Y}$ & $\mathrm{Y}$ & $\mathrm{N}$ \\
\hline $\begin{array}{c}\text { H4: Socio-demographic profile influences ethically } \\
\text { conscious behavior }\end{array}$ & $\mathrm{Y}$ & $\mathrm{N}$ & $\mathrm{N}$ \\
\hline H5: Information profile influences issue recognition & $\mathrm{Y}$ & $\mathrm{Y}$ & $\mathrm{Y}$ \\
\hline $\begin{array}{c}\text { H6: Information profile influences ethical identity } \\
\text { formation }\end{array}$ & $\mathrm{N}$ & $\mathrm{N}$ & $\mathrm{Y}$ \\
\hline $\begin{array}{c}\text { H7: Information profile influences ethically } \\
\text { conscious behavior }\end{array}$ & $\mathrm{N}$ & $\mathrm{N}$ & $\mathrm{Y}$ \\
\hline
\end{tabular}

There could be several possible explanations for the deviating Chinese results. First, they may reflect cultural and social differences in the influence of external pressures vs. internalized moral identities. This may also be the result of social values or way of living. For example Chinese people traveling in trains used to throw their food utensils out of windows. As these utensils were made of clay, this habit did not cause any problem.
However, the new packaging materials made of plastics, essentially non-biodegradable, create serious littering issues. Second, there may be economic factors like purchasing power of consumers that do not let the good intentions convert in good actions. Third, It may also be attributed to the fact that consumer have limited awareness of climate change or the consequences that this issue 
may create. Last, it could be due the limited information available to the public in general.

\section{Conclusion}

This study provides a significant contribution to the existing body of knowledge regarding the determinants of ethically conscious behavior, adapting existing research frameworks and applying it to individual context that is significantly different from the focus of previous studies. The aim of this study was to develop and test an issue contingent ethical decision-making model. All together, the basic elements of the proposed model are found to have a significant role in ethically conscious behavior of consumers. The model has cross-cultural comparability in Europe, USA and China. Yet, the strength of the links between the latent variables varies among the regions. First, the measure of issue recognitions is found to impact positively the ethical identity formation of consumers. Second, ethical identity influences the ethically conscious behaviors of the consumers directly as well as indirectly through ethical intentions. However, among Chinese consumers, the ethical identity, whether in form of ethical predispositions or ethical intentions do not translate into ethical behavior. Third, In line with literature, demographics have mixed impact on the consumers' ethical development and behavior. Finally, information profile of consumers plays important role in ethical identity formation by influencing issue recognition.

The results are consistent with the idea that information has an impact on the consumers' ethical decision-making process. Numerous studies have highlighted the fact that lack of awareness of issue, paucity of product knowledge, dearth of product promotion, and ineffective merchandising has negatively influenced consumers in their choice making for socially desirable products and services (Roddy et al., 1996; Chryssochoidis, 2000). Canavari et al., (2002) referenced thirty studies - concerning organic food choice - to indicate that organic food has been insufficiently promoted and merchandized. Conforming to the literature this study affirms the importance of information diffusion. It furthers the debate by emphasizing the fact that desired changes in consumer behavior will depend on the contents of the information targeted to form consumers' ethical identities. Hence for the information to be effective, it should include the severity of the problem, the certainty of its occurrence, and the fact that consumers are affected by it. The analysis of the data from all three regions shows importance of information diffusion. The companies could benefit from developing strategies to maintain continuous communication for increasing the consumers' level of awareness and enhancing their preferences for ethically conscious companies. The companies would be advised to strengthen their associations with their consumers - through publicity, visible public relations activities, product labeling and certification, and issue driven marketing campaigns - by means of various media.

The study concludes that ethical conscious behavior and ethical intentions are positively related to ethical identities of the consumers. The findings have once again confirmed the importance of self-belief concept in the context of issue contingent decision-making. Hence the consumers, who think that their actions can have an effect in solving a problem, are more likely to engage in an ethically conscious behavior. In addition, consumers are motivated to engage in cognitive efforts in their issue contingent decision-making when they are well informed and are highly concerned about the issue. Based on this work, further studies can be carried out to see if and how information diffusion strategies can be formulated to stimulate the self-belief aspect of consumers' ethical personality.

As a whole, the findings of the study have highlighted that environmentally conscious consumers are more likely to engage in environmental friendly gestures, hence making them a natural target for environment-friendly product marketer. The results suggest that marketers of environment-friendly products should appeal three subdivisions of consumers' belief 
structure in their communication; the information part (educating and informing about an issue), the concern part (demonstrating the evils of the issue), and self-belief part (showing that consumers' contribution matter in resolving the issue). Moreover, this implies that demand of environment-friendly products may be enhanced by appealing on environmental beliefs or by focusing on the product features linking to environmental beliefs or both. An ethically conscious behavior whether in form of an environment friendly purchase or consumption, requires additional work of consumers in form of time, money or effort. Moreover, the benefits offered by environment friendly products are often implicit, difficult to comprehend, and often add-on in nature. Therefore the need for effective communication to consumers is obvious to realize ethical behaviors.

Consumers' buying behavior is influenced by a number of factors such as price, quality, and convenience. The results of this research work do not diminish the importance of such factors. What is emphasized is the fact that 'environment-friendliness' can influence the consumer choice for otherwise comparable products. Also consumers having high concern for ecological issues may prefer to buy such products even when they have to pay a slight premium in shape of money, time or effort.

The findings also yield public policy recommendations for stimulating ethically conscious and environment friendly behaviors among the citizens. The environmental information is often complex and difficult comprehend due to time lag. So it is important that such information is translated for laypersons. Most importantly, this study shows that ethical consumer behaviors can be stimulated through raising issue certainty levels and enhancing information clarity, increasing social concern and involvement, and focusing on the importance of individual efforts. The public sensitizing campaigns should centre on information diffusion and ethical identity development aspects of individual decisionmaking process. The importance of individual contributions to collective sustainability and ecology goals must be highlighted.

Socio-demographic characteristics have been widely used for segmenting and profiling environment-friendly consumers with confusing and conflicting results. A more psychographic approach focusing on values, identities, and lifestyles could better provide a deeper understanding on the specific causes of consumer behavior and choice. In addition this could also help segment environmentally concisions consumers more effectively. Thus, the customer segmentation issue presents a promising focus for further research

This study implies that issue awareness and recognition is an important prerequisite for ethically conscious behavior. Yet, it might be necessary to distinguish between various levels or stages of individual awareness. Additionally stages of collective consumer awareness at societal and national may also give clue to the variations found among consumers of different cultural backgrounds and nationalities. The three regions used in the study serve to increase the validity and generalizability of the findings. However, the results cannot be generalized to consumers from all the regions and countries. It would be worthwhile to test this, or similar models, in different cultural context. Researchers could also examine other moderators of the relationships we tested in our model. Moreover, a better understanding of the influences of various sources of information available to consumers may help marketers' better target individual customers.

\section{References}

Aertsens, J., Verbeke, W., Mondelaers, K., \& HuYlenbroecK, G. V. (2009). 'Personal determinants of organic food consumption: a review'. British Food Journal, 111(10), 11401167.

Agarwal, J., \& Malhotra, N. K. (2005). 'An integrated model of attitude and affect: Theoretical foundation and an empirical 
investigation'. Journal of Business Research, 58(4), 483-493.

AJZEN, I. (1985). 'From intentions to actions: A theory of planned behavior. In J. Kuhl \& J.Beckman (Eds.), Action-control: From cognition to behavior, 11-39.

AJZEN, I. (1991). 'The theory of planned behavior'. Organizational Behavior and Human Decision Processes, 50(2), 179-211.

AJZEN, I. (2001). 'Nature and operation of attitudes'. Annual Review of Psychology, 52, 27-58.

Aquino, K., \& ReED II, A. (2002). 'The SelfImportance of Moral Identity'. Journal of Personality \& Social Psychology, 83(6), 14231440.

ARBuCKLE, J.L. (2006), Amos 7.0 User's Guide. PA: Amos Development Corporation, Spring House.

ARmitaGe, C.J., \& ConNer, M. (2001). 'Efficacy of the Theory of Planned Behaviour: A meta analytic review'. British Journal of Social Psychology, 40(4), 471-499.

Auger, P., Devinney, T.M., Louviere, J.J., BuRke, P.F. (2008). 'Do social product features have value to consumers?' International Journal of Research in Marketing 25(3), 183-191.

BAGozZI, R.P., AND KimmeL, S.K. (1995). 'A comparison of leading theories for the prediction of goal-directed behaviours'. British Journal of Social Psychology, 34(4), 437-461.

BAmberg, S., \& Moser, G. (2007). 'Twenty years after Hines, Hungerford, and Tomera: A new meta-analysis of psycho-social determinants of pro-environmental behaviour'. Journal of Environmental Psychology, 27(1), 14-25.

Beauchamp, T.L., \& Bowie, N.E. (2004). Ethical theory and business. Pearson Education.

BLASI, A. (1984). Moral identity: Its role in moral functioning. In W. M. KuRTINES \& J. L. GEWIRTZ (Eds.), Morality, moral behavior, and moral development. 128-139. New York: John Wiley \& Sons.

BRAY, J., Johns, N., \& KilbuRn, D. (2010). 'An Exploratory Study into the Factors Impeding Ethical Consumption'. Journal of Business Ethics, 98(4), 597-608.

BRoWne, A.W., HaRris, P.J.C., HofNY-Collins, A.H., PASieCZniK, N., \& WALlace, R.R. (2000). 'Organic production and ethical trade: definition, practice and links'. Food Policy, 25(1), 69-89.

CARrigan, M., SZMigin, I., \& WRight, J. (2004). 'Shopping for a better world? An interpretive study of the potential for ethical consumption within the older market'. Journal of Consumer Marketing, 21(6), 401-417.

Carrington, M.J., Neville, B.A. \& Whitwell, G.J. (2010). 'Why Ethical Consumer Don't Walk Their Talk: Towards a Framework for Understanding the Gap Between the Ethical Purchase Intentions and Actual Buying Behaviour of Ethically Minded Consumers'. Journal of Business Ethics, 97, 139-158.

CHAN, K. (1998). 'Mass communication and pro-environmental behavior: waste recycling in Hong Kong'. Journal of Environmental Management, 52(4), 317-325.

Chatzidakis, A., Hibbert, S., \& SMith, A.P. (2007). 'Why People Don't Take their Concerns about Fair Trade to the Supermarket: The Role of Neutralisation'. Journal of Business Ethics, 74(1), 89-100.

CHEN, M.F. (2007). 'Consumer attitudes and purchase intentions in relation to organic foods in Taiwan: Moderating effects of foodrelated personality traits'. Food Quality and Preference, 18(7), 1008-1021.

ChO. S., \& CRASSER.A.H. (2011). 'What makes us care? The impact of cultural values, individual factors, and attention to media content on motivation for ethical consumerism'. International social science review, 86(1/2), 3-23.

Conner, M., \& ARMitage, C.J. (1998). 'Extending the Theory of Planned Behavior: A 
Review and Avenues for Further Research'. Journal of Applied Social Psychology, 28(15), 1429-1464.

CRANE, A. (2001). 'Unpacking the Ethical Product'. Journal of Business Ethics, 30(4), 361-373.

D' Astous, A., \& Legendre, A. (2008). 'Understanding Consumers' Ethical Justifications: A Scale for Appraising Consumers' Reasons for Not Behaving Ethically'. Journal of Business Ethics, 87(2), 255-268.

DEAN, M., RAATS, M.M., \& SHEPhERD, R. (2008). 'Moral Concerns and Consumer Choice of Fresh and Processed Organic Foods1'. Journal of Applied Social Psychology, 38(8), 20882107.

ECKHARDT, G.M., BelK, R., \& Devinney, T.M. (2010). 'Why don't consumers Consume Ethically?' Journal of Consumer Behaviour', $9(6), 426-436$

Ellen, P.S., Joshua L.W., \& Cobb-Walgren, C. (1991). "The Role of Perceived Consumer Effectiveness in Motivating Environmentally Conscious Behaviors'. Journal of Public Policy \& Marketing, 10 (Fall), 102-117.

FERRELL, O.C., \& GREShAM, L.G. (1985). 'A Contingency Framework for Understanding Ethical Decision Making in Marketing'. Journal of Marketing, 49(3), 87-96.

FISHBEIN, M., \& AJZEN, I. (1975). Belief, attitude, intention, and behavior: an introduction to theory and research. Addison-Wesley Pub. Reading, Mass.

ForNell, C., \& LARCKER, D.F. (1981). 'Evaluating structural equation models with unobservable variables and measurement error'. Journal of Marketing Research, 48, 3950.

Godin, G., VAlois, P., \& LePAGE, L. (1993). 'The pattern of influence of perceived behavioral control upon exercising behavior: An application of Ajzen's theory of planned behavior'. Journal of Behavioral Medicine, 16(1), 81-102.
Gracia, A., \& DE Magistris, T. (2007). 'Organic food product purchase behavior: a pilot study for urban consumers in the South of Italy'. Instituto Nacional de Investigación $y$ Tecnología Agraria y Alimentaria (INIA). Retrieved from http://dialnet.unirioja.es/servlet/oaiart?codi go $=2486265$

GRUNERT, S.C., \& JUHL, H.J. (1995). 'Values, environmental attitudes, and buying of organic foods'. Journal of Economic Psychology, 16(1), 39-62.

Hair, J., BlaCK, W., BABin, B., Anderson, R., \& TATHAM, R. (2006). Multivariate data analysis, 6th ed. Pearson Prentice Hall, Upper Saddle River, New Jersey.

HARDY, S.A. (2006). 'Identity, Reasoning, and Emotion: An Empirical Comparison of Three Sources of Moral Motivation'. Motivation and Emotion, 30(3), 205-213.

Harrison, R., NEWholm, T., \& SHAW, D. (2005). The ethical consumer. SAGE.

Honkanen, P., Verplanken, B., \& Olsen, S.O. (2006). 'Ethical values and motives driving organic food choice'. Journal of Consumer Behaviour, 5(5), 420-430.

Hughner, R.S., McDonagh, P., Prothero, A., Shultz II, C.J., \& StAnton, J. (2007). 'Who are organic food consumers? A compilation and review of why people purchase organic food'. Journal of Consumer Behaviour, 6(2-3), 94110.

HunT, S.D., \& Vitell, S. (1986). 'A General Theory of Marketing Ethics'. Journal of Macromarketing, 6(1), 5-16.

JoNES, T.M. (1991). 'Ethical Decision Making by Individuals in Organizations: an Issuecontingent Model'. Academy of Management Review, 16(2), 366-395.

KAISER, F.G. (2006). 'A moral extension of the theory of planned behavior: norms and anticipated feelings of regret in conservationism'. Personality and Individual Differences, 41(1), 71-81. 
KILHAM, W., \& MANN, L. (1974). 'Level of Destructive Obedience as a Function of Transmitter and Executants Roles in the Milgram Obedience Paradigm'. Journal of Personality and Social Psychology, 29(5), 696-702.

Kim, J.O., Forsythe, S., Gu, Q., And Moon, S.J. (2002). 'Cross-Cultural Consumer Values, Needs and Purchase Behavior'. The Journal of Consumer Marketing, 19(6), 481-502.

KIM, S.S. (2009). 'The Integrative Framework of Technology Use: an Extension and Test'. MISQ, 33(3), 513-537.

KlÖCKNER, C.A., \& OHMS, S. (2009). 'The Importance of Personal Norms for Purchasing Organic Milk'. British Food Journal, 111(11), 1173-1187.

LEE, J.A., \& HOLDEN, S.J.S. (1999). 'Understanding The determinants of Environmentally Conscious Behavior'. Psychology and Marketing, 16(5), 373-392.

LiN, C.H., Gregor, S., AND EWING, M. (2008). 'Developing a Scale to Measure the Enjoyment of Web Experiences'. Journal of Interactive Marketing, 22(4), 40-57.

Loe, T., Ferrell, L., \& Mansfield, P. (2000). 'A Review of Empirical Studies Assessing Ethical Decision-Making in Business'. Journal of Business Ethics, 25(3), 185 - 204.

Michaelidou, N., \& HaSSAN, L.M. (2008). 'The Role of Health Consciousness, Food Safety Concern and Ethical Identity on Attitudes and Intentions Towards Organic Food'. International Journal of Consumer Studies, 32(2), 163-170.

Nicholls, A., \& LEE, N. (2006). 'Purchase Decision-making in Fair Trade and the Ethical Purchase "gap": "is there a fair trade twix?'. Journal of Strategic Marketing, 14(4), 369-386.

NoRMAN, P., \& SMITH, L. (1995). 'The Theory of Planned Behaviour and Exercise: An Iinvestigation into the Role of Prior Behaviour, Behavioural Intentions and
Attitude Variability'. European Journal of Social Psychology, 25(4), 403-415.

Ozcaglar-Toulouse, N., Shiu, E., \& ShaW, D. (2006). 'In Search of Fair Trade: Ethical Consumer Decision Making in France'. International Journal of Consumer Studies, 30(5), 502-514.

Polonsky, M.J., Brito, P.Q., Pinto, J., \& HiggsKLEYN, N. (2001). 'Consumer Ethics in the European Union: A Comparison of Northern and Southern Views'. Journal of Business Ethics, 31(2), 117-130.

ReED, A., 2ND, \& Aquino, K.F. (2003). 'Moral Identity and the Expanding Circle of Moral Regard Toward Out-groups'. Journal of Personality and Social Psychology, 84(6), 1270-1286.

REST, J.R. (1986). Moral development: advances in research and theory. Praeger.

REYnoldS, S.J. (2006). 'Moral Awareness and Ethical Predispositions: Investigating the Role of Individual Differences in the Recognition of Moral Issues'. Journal of Applied Psychology, 91(1), 233-243.

RoBerts J.A. (1996). 'Green Consumers in the 1990s: Profile and Implications for Advertising'. Journal of Business Research, 36, 217-231.

RoberTs, J.A., \& BACON, D.R. (1997). 'Exploring the Subtle Relationships between Environmental Concern and Ecologically Conscious Consumer Behavior'. Journal of Business Research, 40(1), 79-89.

Robinson, R., \& SMith, C. (2002). 'Psychosocial and Demographic Variables Associated with Consumer Intention to Purchase Sustainably Produced Foods as Defined by the Midwest Food Alliance'. Journal of Nutrition Education and Behavior, 34(6), 316-325.

RotTER, J.B. (1966). 'Generalized Expectancies for Internal Versus External Locus of Control of Reinforcement'. Psychological Monographs, $80(1), 1-28$. 
SABA, A., \& MessinA, F. (2003). 'Attitudes towards organic foods and risk/benefit perception associated with pesticides'. Food Quality and Preference, 14(8), 637-645.

SCHLEGELMilCH, B.B., BOHLEN, G.M., \& Diamantopoulos, A. (1996). 'The link between green purchasing decisions and measures of environmental consciousness'. European Journal of Marketing, 30(5), 35-55.

SCHWARTZ, S.H. (1977). 'Normative Influences on Altruism'. Advances in Experimental Social Psychology, 10, 221-279.

SCHWARTZ, S.H. (1992). Universals in the Content and Structure of Values: Theoretical Advances and Empirical Tests in 20 countries. In M. P. Zanna (Ed.), Advances in experimental social psychology. San Diego, CA: Academic Press. 25, 1-65.

SDC (Sustainable Development Commission), (2003). A Vision for Sustainable Agriculture. $30^{\text {th }}$ October. URL: http://www.sdcommission.gov.uk/pubs/food2001/index.ht $\mathrm{m}$

Sha0, R., Aquino, K., \& Freeman, D. (2008a). 'Beyond moral reasoning: A review of moral identity research and its implications for business ethics'. Business Ethics Quarterly, 18(4), 513-540.

SHAW, D., \& SHIU, E. (2002a). 'An Assessment of Ethical Obligation and Self-identity in Ethical Consumer Decision-making: A Structural Equation Modelling Approach'. International Journal of Consumer Studies, 26(4), 286-293.

SHaW, D., \& SHIU, E. (2002b). 'The Role of Ethical Obligation and Self-identity in Ethical Consumer Choice'. International Journal of Consumer Studies, 26(2), 109-116.

SHAW, D., \& SHIU, E. (2003). 'Ethics in Consumer Choice: A Multivariate Modelling Approach'. European' Journal of Marketing, 37(10), 1485-1498.

ShaW, D., ShiU, E., \& Clarke I. (2000). 'The Contribution of Ethical Obligation and Selfidentity to the Theory of Planned Behaviour:
An Exploration of Ethical Consumers'. Journal of Marketing Management, 16(8), 879-94.

SMith, J.R., Terry, D.J., MANSTEAD, A.S., LOUIS, W. R., Kotterman, D., \& WolfS, J. (2008). 'The Attitude-Behavior Relationship in Consumer Conduct: The Role of Norms, Past Behavior, and Self-Identity'. Journal of Social Psychology, 148(3), 311-334.

Stern, P.C., \& DieTZ, T. (1994). 'The Value Basis of Environmental Concern'. Journal of Social Issues, 50(3), 65-84.

STRYKER, S. (2000). 'Identity Competition: Key to Differential Social Movement Participation. p 21-41 in Self, Identity and Social Movements, edited by Sheldon Stryker, Timothy Owens, and Robert White. Minneapolis: University of Minnesota Press.

Thøgersen, J., \& Ölander, F. (2003). 'Spillover of Environment-friendly Consumer Behaviour'. Journal of Environmental Psychology, 23(3), 225-236.

Thorbjørnsen, H., Pedersen, P.E., \& Nysveen, H. (2007). "'This is who i am": Identity Expressiveness and the Theory of Planned Behavior'. Psychology and Marketing, 24(9), 763-785.

Trevino, L.K. (1986). 'Ethical Decision Making in Organizations: A Person-Situation Interactionist Model'. The Academy of Management Review, 11(3), 601-617.

VAN DE Velde, L., Verbeke, W., PopP, M., Buysse, J., \& VAn Huylenbroeck, G. (2009). 'Perceived Importance of Fuel Characteristics and its Match with Consumer Beliefs about Biofuels in Belgium'. Energy Policy, 37(8), 3183-3193.

Verhoef, P.C. (2005). 'Explaining Purchases of Organic Meat by Dutch Consumers'. European Review of Agricultural Economics, 32(2), 245267.

Vermeir, I., \& VerbeKe, W. (2006). 'Sustainable Food Consumption: Exploring the Consumer "Attitude - Behavioral Intention" Gap'. Journal of Agricultural and Environmental Ethics, 19(2), 169-194. 
Vermeir, I., \& Verbeke, W. (2008). 'Sustainable food consumption among young adults in Belgium: Theory of planned behaviour and the role of confidence and values'. Ecological Economics, 64(3), 542-553.

WilLER, H., \& KILCHER, L. (2009). 'The World of Organic Agriculture - Statistics and Emerging Trends 2009. IFOAM, Bonn; FiBL, Frick; ITC, Genf. Retrieved from http://orgprints.org/15575/1/willer\%2Dkil cher\%2D2009.pdf

YeOnSHIN, K., \& ChoI, S.M., (2005). 'Antecedents of Green Purchase Behavior: An
Examination of Collectivism, Environmental Concern, and PCE'. Advances in Consumer Research, 32(1), 592-599.

ZANDER, K., \& HAMm, U. (2010). 'Consumer preferences for additional ethical attributes of organic food'. Food Quality and Preference, 21(5), 495-503.

ZANnA, M. P. (1992). Advances in Experimental Social Psychology. San Diego: Academic Press. 